\author{
Janina Pach \\ Uniwersytet Pedagogiczny \\ im. Komisji Edukacji Narodowej \\ w Krakowie \\ Mieczysława Solińska \\ Politechnika Krakowska \\ im. Tadeusza Kościuszki
}

\title{
Problem pomocy dla małych i średnich przedsiębiorstw w Polsce po akcesji do Unii Europejskiej
}

\author{
„Przedsiębiorcy to ekonomiczne DNA, którego potrzebujemy, aby rozwijać \\ konkurencyjność i innowacje w Europie"
}

Günter Verheugen, wiceprzewodniczący Komisji Europejskiej odpowiedzialny za przedsiębiorstwa i przemysł

Małe i średnie przedsiębiorstwa (dalej MŚP) nabierają coraz większego znaczenia w gospodarce krajów Unii Europejskiej, w tym w Polsce. Stanowią one ważne źródło zatrudnienia i są kluczowymi podmiotami działającymi na rzecz dobrobytu społeczności lokalnych i regionalnych. Dlatego też Akt dla drobnej przedsiębiorczości w Europie po raz pierwszy proponuje stworzenie kompleksowych ram polityki dla Unii Europejskiej i jej państw członkowskich. Opiera się on na przekonaniu, że przedsiębiorczość i przedsiębiorcy powinni być doceniani i wynagradzani, ponieważ stanowią podporę naszego społeczeństwa. Polityka przyjazna dla MŚP powinna się stać podstawowym wyznacznikiem działań w Unii Europejskiej, winna zostać na zawsze włączona do procesu tworzenia wspólnotowych polityk. Dotyczy to wprowadzania regulacji w zakresie powstawania, funkcjonowania i pomocy dla małych i średnich przedsiębiorstw oraz dostarczania dóbr i usług dla społeczeństwa1.

Istnieją jednak pewne ograniczenia wspierania MŚP i udzielania im pomocy ze strony rządów krajów ich lokalizacji. Wynikają one ze wspólnej polityki konkurencji Unii Europejskiej, której jednym z filarów jest zakaz pomocy publicznej. Deformuje ona i ogranicza konkurencję, będącą kołem zamachowym rozwoju gospodarczego. To sprawia, że obowiązujące przepisy dotyczące MŚP dopuszczają jedynie pomoc warunkową dla sektora małych i średnich przedsiębiorstw, nienaruszającą konkurencji. Określają między innymi: rodzaj i wielkość pomocy, jej intensywność, warunki i okoliczności jej udzielenia, okres przyznania pomocy itd. Ponadto przepisy te kładą nacisk na wszelkie działania mające usunąć przeszkody tam, gdzie utrudniają one tworzenie ram powstania MŚP i ich funkcjonowania.

\footnotetext{
${ }^{1}$ Stawiajac na małe firmy, Europa jest dobra dla MŚP, MŚP sq dobre dla Europy, Komisja Europejska,
} Przedsiębiorstwa i przemyst, wydanie $2008 \mathrm{r}$. 


\section{Sektor MŚP w Polsce na tle Unii Europejskiej}

Sektor małych i średnich przedsiębiorstw stanowi podstawę przedsiębiorczości w Unii Europejskiej, ponieważ ${ }^{2}$ :

- stanowi 99,8\% wszystkich europejskich firm,

- dostarcza $67,1 \%$ miejsc pracy w sektorze prywatnym,

- zatrudnia ponad 80\% pracowników w niektórych sektorach przemysłu, np. w sektorze produkcji wyrobów metalowych, budownictwa i meblarstwa ${ }^{3}$.

Sektor ten jest zróżnicowany w poszczególnych krajach Unii pod wieloma względami, w tym ${ }^{4}$ :

- struktury MŚP, tzn. udziału mikro-, małych i średnich przedsiębiorstw. Szczególne znaczenie mają mikroprzedsiębiorstwa określane gigantami gospodarki europejskiej, stanowiące 91,5\% wszystkich przedsiębiorstw, mniejsze natomiast znaczenie mają małe przedsiębiorstwa stanowiące 7,3\% wszystkich, średnie $(1,1 \%)$ i duże (tylko $0,2 \%$ ),

- wielkości zatrudnienia ogółem oraz w poszczególnych typach przedsiębiorstw,

- wielkości obrotu, wartości dodanej, udziału eksportu w całkowitej sprzedaży,

- dziedzin lokalizacji: przemysł, transport i łączność, handel, budownictwo, obrót nieruchomościami itp.

- aktywności i przeżywalności firm tego sektora oraz pod wieloma innymi względami. Pomimo zróżnicowania tego sektora jego znaczenie jest ogromne. Wynika to z wielu względów, w tym przede wszystkim z:

a) dużej elastyczności przedsiębiorstw tego sektora w dostosowywaniu do zmieniającego się popytu na rynku,

b) niskiej kapitałochłonności produkcji powodującej oszczędność w kosztach funkcjonowania,

c) szczególnej roli właściciela, sytuującej go jako menedżera firmy,

d) wysokiego poziomu motywacji przedsiębiorcy, wynikającego ze ścisłego związku między rentownością firmy a jego dochodami,

e) ograniczonej biurokracji wpływającej na szybkość podejmowania decyzji i przepływ informacji,

f) wysokiego udziału w kreacji nowych miejsc pracy i elastyczności polityki zatrudnienia,

g) silnego wpływu na rozwój lokalnej przedsiębiorczości i innowacyjności.

Dynamiczny rozwój sektora małych i średnich przedsiębiorstw w Polsce po 1989 roku związany jest z procesem transformacji gospodarczej połączonej z liberalizacją i urynkowieniem, którego podstawą stała się prywatyzacja kapitałowa, likwidacyjna i założycielska. Od 1989 roku do chwili obecnej wyróżnić można cztery fazy rozwoju sektora MŚP.

Pierwsza faza rozwoju, nazwana fazą wstępnego rozwoju przedsiębiorczości, rozpoczęła się jeszcze w okresie gospodarki centralnie planowanej, po wprowadzeniu korzystnych dla rozwoju przedsiębiorczości regulacji prawnych. Dotyczy to podejmowanych prób reformowania gospodarki w latach osiemdziesiątych. Zgodnie z założeniami programu reform funkcjonowanie gospodarki miało być oparte na trzech filarach: samodzielnym przedsiębiorstwie, centralnym planowaniu i pośrednich narzędziach polityki gospodarczej. Na szczególne podkreślenie zasługuje ustawa o przedsiębiorstwie państwowym z 1981 roku, a także ustawy

\footnotetext{
${ }^{2}$ Eurostat, kluczowe wskaźniki dla sektora niefinansowego, UE 27, 2005.

${ }^{3}$ Eurostat, kluczowe wskaźniki dla sektora niefinansowego, UE 27, 2005.

${ }^{4}$ Szerzej: J. Pach, Znaczenie matych i średnich przedsiębiorstw po 2000 roku [w:] Rola przedsiębiorczości w gospodarce opartej na wiedzy, red. Z. Zioło i T. Rachwał, Warszawa-Kraków 2008, s. 90-107.
} 
o podejmowaniu działalności gospodarczej oraz działalności gospodarczej z udziałem podmiotów zagranicznych z 1988 roku. Pomimo iż reformy wprowadzane w latach osiemdziesiątych nie miały charakteru w pełni rynkowego (były zorientowane na tzw. parametryczny system zarządzania) to poprawiały efektywność działania firm i przyczyniały się do wzrostu przedsiębiorczości.

Kolejna faza, która miała miejsce po 1989 roku, charakteryzowała się dynamicznym rozwojem sektora. Zwiększała się wówczas zarówno liczba podmiotów sektora MŚP, jak i wzrastał ich udział w tworzeniu PKB. Przedsiębiorstwa powstawały w efekcie dwóch zasadniczych procesów: przez prywatyzację założycielską oraz prywatyzację przedsiębiorstw państwowych drogą kapitałową i likwidacyjną. W latach 1989-1994 dynamika wzrostu liczby przedsiębiorstw sektora MŚP była bardzo wysoka (nastappił ponad dwukrotny wzrost liczby przedsiębiorstw - w 1994 roku liczba przedsiębiorstw MŚP przekroczyła 2 mln podmiotów) ${ }^{5}$.

Trzecią fazą był etap samoregulacji rynkowej, charakteryzujący się stabilizacją tempa wzrostu liczby podmiotów. Liczba podmiotów stale rosła, lecz tempo tego wzrostu było mniejsze niż przed 1995 rokiem. W latach 2001-2003 nastapiło wyhamowanie dynamiki liczby podmiotów gospodarczych sektora, głównie za sprawą spadku liczby przedsiębiorstw średniej wielkości. Przyczyn tej tendencji można upatrywać w spowolnieniu gospodarczym, jakie miało miejsce w tym okresie.

Kolejnym ważnym etapem w rozwoju sektora MŚP była akcesja Polski do Unii Europejskiej 1 maja 2004 roku, rozpoczynająca fazę integracji przedsiębiorczości europejskiej. Po 2004 roku liczba przedsiębiorstw sektora MŚP ponownie wzrosła, a w roku 2007 w porównaniu z rokiem 1999 liczba firm analizowanego sektora zwiększyła się blisko o 25\%. Bliższe analizy pokazują, iż w analizowanym okresie liczba i kondycja przedsiębiorstw sektora MŚP, aktywność (rzeczywiste funkcjonowanie) oraz przeżywalność (okres przetrwania) była bardzo zróżnicowana.

\section{Małe i średnie przedsiębiorstwa zarejestrowane i aktywne w Polsce}

Na przestrzeni lat 2003-2007 liczba przedsiębiorstw zarejestrowanych w REGON rosła w zróżnicowanym tempie. O ile w 2003 roku wyniosła 3,64 mln, w 2004 roku 3,67 mln, w 2005 roku 3,72 mln, w 2006 roku już 3,74 mln, to w 2007 roku osiagnęła 3,79 mln. Liczby małych i średnich przedsiębiorstw zarejestrowanych w REGON i aktywnych nie pokrywały się, a w poszczególnych latach znacznie od siebie odbiegały. Duża część przedsiębiorstw zarejestrowanych $\mathrm{w}$ analizowanym okresie z różnych przyczyn nie podjęła $\mathrm{w}$ ogóle działalności lub zrobiła to z opóźnieniem. Aktywność podmiotów sektora przedsiębiorstw (obliczona jako odsetek firm aktywnych zarejestrowanych w REGON) utrzymywała się na bardzo niskim poziomie oscylującym w latach 2003-2007 w granicach 45,1\%-47,4\%, por. tab. 1 .

Wynikać to mogło z trudności w uruchomieniu działalności gospodarczej czy z małego doświadczenia przedsiębiorców, dla których niejednokrotnie założona firma stanowiła pierwsze doświadczenie pracy na ,swoim”. Z tabeli wynika, iż wśród przedsiębiorstw zarejestrowanych w REGON największą aktywność posiadały duże firmy, a najmniejszą - małe, zatrudniające od 10 do 49 osób.

W 2007 roku aktywność ta wzrosła znacząco w dużych firmach, co wynikać mogło z większego dostępu do środków finansowych, ze wzrostu umiejętności kadr zarządzających, dostępu do informacji rynkowych oraz większych kontaktów z europejskimi przedsiębiorcami po wejściu Polski do Unii Europejskiej.

\footnotetext{
${ }^{5}$ E. Niemyska, Pomoc publiczna dla matych i średnich przedsiębiorstw w okresie dekoniunktury gospodarczej, Polska Agencja Informacji i Inwestycji.
} 
Tab. 1. Udział przedsiębiorstw aktywnych w liczbie przedsiębiorstw zarejestrowanych w REGON według klasy wielkości w latach 2003-2007 w \%

\begin{tabular}{|c|c|c|c|c|c|}
\hline Lata & Ogółem & $\begin{array}{c}\text { Mikro, } \\
\text { zatrudniające } \\
\text { poniżej } \\
\text { 10 pracowników }\end{array}$ & $\begin{array}{c}\text { Małe, zatrudniające } \\
\text { od 10 do 49 } \\
\text { pracowników }\end{array}$ & $\begin{array}{c}\text { Średnie, } \\
\text { zatrudniające } \\
\text { od 50 do 249 } \\
\text { pracowników }\end{array}$ & $\begin{array}{c}\text { zatrudniające } \\
\text { od 250 } \\
\text { pracowników }\end{array}$ \\
\hline 2003 & 47,4 & 48,1 & 29,6 & 47,7 & 44,9 \\
\hline 2004 & 46,7 & 47,4 & 29,7 & 46,6 & 47,8 \\
\hline 2005 & 45,1 & 45,8 & 28,8 & 47,2 & 51,5 \\
\hline 2006 & 45,8 & 46,6 & 28,3 & 48,7 & 54,8 \\
\hline 2007 & 46,8 & 47,6 & 28,3 & 51,1 & 59,3 \\
\hline
\end{tabular}

Źródło: opracowanie własne na podstawie Raportu o stanie sektora małych i średnich przedsiębiorstw w Polsce w latach 2003-2008, Polska Agencja Rozwoju Przedsiębiorczości 2009, s. 32.

Struktura sektora MŚP pod względem aktywności wykazywała ogromne zróżnicowanie, por. tab. 2.

Tab. 2. Liczba przedsiębiorstw aktywnych w latach 2003-2007

\begin{tabular}{|l|c|c|c|c|c|c|}
\hline \multicolumn{1}{|c|}{ Przedsiębiorstwa } & $\mathbf{1 9 8 9}$ & $\mathbf{2 0 0 3}$ & $\mathbf{2 0 0 4}$ & $\mathbf{2 0 0 5}$ & $\mathbf{2 0 0 6}$ & $\mathbf{2 0 0 7}$ \\
\hline MŚP ogółem & 181600 & 1723834 & 1712229 & 1673940 & 1711934 & 1773830 \\
\hline Mikro & 1760,6 & 1666696 & 1653856 & 1615167 & 1652998 & 1713194 \\
\hline Małe (bez mikro) & 41,1 & 42770 & 44370 & 44519 & 44228 & 45184 \\
\hline Średnie & 14,3 & 14368 & 14003 & 14254 & 14708 & 15452 \\
\hline $\begin{array}{l}\text { Aktywne, jako\% } \\
\text { zarejestrowanych }\end{array}$ & 54,18 & 47,4 & 46,9 & 45,2 & 45,8 & 46,8 \\
\hline
\end{tabular}

Źródło: opracowanie własne na podstawie Raportu o stanie sektora małych i średnich przedsiębiorstw w Polsce w latach 2007-2008, Polska Agencja Rozwoju Przedsiębiorczości 2009, s. 24.

Po 2003 roku wystapił wzrost ogólnej liczby małych i średnich przedsiębiorstw, na co niewątpliwie wpływ miała akcesja Polski do Unii Europejskiej. W 2007 roku liczba przedsiębiorstw sektora MŚP w stosunku do 1999 wzrosła o blisko 1/4, przy czym najwyższą dynamiką charakteryzowały się przedsiębiorstwa małe.

W 2007 roku w strukturze sektora MŚP w Polsce dominowały przedsiębiorstwa małe oraz mikro-, stanowiące 99\% przedsiębiorstw zarejestrowanych w REGON, zaś średnie stanowiły około 1\%. Struktura branżowa sektora $\mathrm{MS}^{6} \mathrm{P}^{6} \mathrm{w}$ Polsce jest zatem podobna jak w UE. Małe i średnie przedsiębiorstwa dominują w sekcjach: handel hurtowy i detaliczny (27\%), obsługa nieruchomości (22\%), przetwórstwo przemysłowe (13\%), budownictwo (11\%). W przeliczeniu na 1000 mieszkańców liczba małych i średnich przedsiębiorstw była zróżnicowana w poszczególnych województwach. Wynikało to z infrastruktury gospodarczej, instytucji otoczenia biznesu, obfitości zasobów ludzkich, tradycji przedsiębiorczych itp. ${ }^{6}$ Raport o stanie sektora matych i średnich przedsiębiorstw w Polsce w latach 2007-2008, Polska Agen-
cja Rozwoju Przedsiębiorczości 2009, s. 31-32. 
Poziom przedsiębiorczości w Polsce (pomimo wzrostu liczby MŚP) charakteryzowany liczbą przedsiębiorstw przypadających na 1000 mieszkańców, w stosunku do innych krajów europejskich wypada przeciętnie. Polska zajmuje pod tym względem 15 miejsce wśród krajów Unii Europejskiej. Poziom przedsiębiorczości mierzony liczbą małych i średnich przedsiębiorstw na 1000 mieszkańców najwyższy jest w Czechach, Portugalii i Grecji, najniższy zaś na Słowacji i w Rumunii.

\section{Udzial firm małych i średnich w tworzeniu PKB}

Jednym z kryteriów znaczenia sektora MŚP w gospodarce jest jego wkład w tworzenie PKB, kształtowanie struktury wytwarzanego PKB, udział w zatrudnieniu itp. Wkład przedsiębiorstw sektora MŚP w tworzenie produktu krajowego brutto wyniósł w 2007 r. 47,4\% (w tym przedsiębiorstwa mikro wytworzyły 30,1\%, małe - 7,3\%, zaś średnie - 10,0\%), por. tab. 3 .

Tab. 3. Udział MŚP w tworzeniu PKB w latach 2003-2008

\begin{tabular}{|l|c|c|c|c|c|}
\hline Przedsiębiorstwa & $\mathbf{2 0 0 3}$ & $\mathbf{2 0 0 4}$ & $\mathbf{2 0 0 5}$ & $\mathbf{2 0 0 6}$ & $\mathbf{2 0 0 7}$ \\
\hline Mikro & 32 & 31,3 & 31,4 & 31 & 30,1 \\
\hline Małe (bez mikro) & 7,5 & 6,8 & 7,3 & 7,4 & 7,3 \\
\hline Średnie & 8,4 & 9,5 & 8,8 & 9,3 & 10,0 \\
\hline MŚP ogółem & 47,9 & 47,6 & 47,5 & 47,7 & 47,4 \\
\hline
\end{tabular}

Źródło: Raport o stanie sektora małych i średnich przedsiębiorstw w Polsce w latach 2007-2008, Polska Agencja Rozwoju Przedsiębiorczości 2009, s. 25.

Struktura wytwarzanego PKB przez ten sektor wyraźnie wskazuje na dominację firm mikro, które w analizowanym okresie wytwarzały ponad 30\% PKB. Przedsiębiorstwa małe (bez mikro) nie przekroczyły poziomu 7,5\% a średnie - wielkości 10\%. Charakterystyczne jest to, że udział MŚP w tworzeniu PKB w okresie 2003-2008 nie wzrastał, był stabilny.

Biorąc pod uwagę lokalizację branżową firm sektora MŚP, należy podkreślić, iż największy udział wartościowy w tworzeniu PKB miały mikroprzedsiębiorstwa prywatne funkcjonujące w handlu i naprawach. Wynikało to z ich dużej liczby i z rosnącego popytu na tego typu usługi $\mathrm{z}$ jednej strony. Natomiast w produkcji przemysłowej największe znaczenie miały przedsiębiorstwa średnie oraz przedsiębiorstwa stanowiące własność publiczną, por. tab. 4.

Należy podkreślić znaczny udział całego sektora MŚP w wytwarzaniu PKB w takich sekcjach, jak: handel i naprawy, budownictwo, działalność usługowa i komunalna, obsługa nieruchomości i firm. Małe i średnie przedsiębiorstwa odgrywają również ogromną i stale rosnącą rolę w gospodarce globalnej, w tym w handlu, w postępie technologicznym, w działalności usługowej ${ }^{7}$. Istnieją jednak rozbieżności w kwalifikowaniu przedsiębiorstw do tego sektora, co utrudnia porównywalność. W USA pojęciem sektora MŚP obejmuje się przedsiębiorstwa, które zatrudniają mniej niż 500 osób, w Unii Europejskiej - przedsiębiorstwa zatrudniające poniżej 250 osób.

\footnotetext{
${ }^{7}$ Zoltan J. Acs, Bernard Young, Small and Medium Sized Enterprises in the Global Economy, University of Maryland 1995, s. 1-9.
} 
Tab. 4. Udział MŚP (sektora prywatnego) w PKB (w cenach bieżących w mln zł) w 2007 roku

\begin{tabular}{|c|c|c|c|c|}
\hline Sekcje & $\begin{array}{c}\text { Ogółem PKB } \\
\text { w poszczególnych } \\
\text { sekcjach }\end{array}$ & $\begin{array}{c}\text { Małe } \\
\text { przedsiębior- } \\
\text { stwa }\end{array}$ & $\begin{array}{l}\text { W tym mikro } \\
\text { (zatr. do } 9 \\
\text { osób) }\end{array}$ & $\begin{array}{l}\text { Średnie } \\
\text { przedsiębior- } \\
\text { stwa }\end{array}$ \\
\hline Górnictwo i kopalnictwo & 22841,00 & 677,40 & 315,20 & 1505,50 \\
\hline Działalność produkcyjna & 194681,00 & 48703,30 & 28613,10 & 36473,20 \\
\hline $\begin{array}{l}\text { Zaopatrywanie w energię } \\
\text { elektryczną, gaz i wodę }\end{array}$ & 34469,00 & 1774,60 & 676,10 & 4954,30 \\
\hline Budownictwo & 75185,00 & 53154,60 & 42766,30 & 10229,90 \\
\hline Handel i naprawy & 189932,00 & 147633,50 & 123525,20 & 19080,10 \\
\hline Hotele i restauracje & 12998,00 & 9674,60 & 7195,30 & 1253,20 \\
\hline $\begin{array}{l}\text { Transport, składowanie } \\
\text { i łączność }\end{array}$ & 72119,00 & 27544,00 & 23195,70 & 7194,90 \\
\hline Pośrednictwo finansowe & 52939,00 & 8033,30 & 2807,90 & 20390,90 \\
\hline $\begin{array}{l}\text { Obsługa nieruchomości } \\
\text { i firm }\end{array}$ & 138325,00 & 108101,10 & 98193,70 & 12055,90 \\
\hline Edukacja & 49245,00 & 3972,30 & 1748,80 & 139,40 \\
\hline $\begin{array}{l}\text { Ochrona zdrowia } \\
\text { i opieka socjalna }\end{array}$ & 37344,00 & 11553,30 & 8785,30 & 1479,30 \\
\hline $\begin{array}{l}\text { Pozostała działalność } \\
\text { usługowa i komunalna, } \\
\text { socjalna i indywidualna }\end{array}$ & 37753,00 & 10836,80 & 9202,50 & 1789,70 \\
\hline $\begin{array}{l}\text { Gospodarstwa domowe } \\
\text { zatrudniające } \\
\text { pracowników }\end{array}$ & 5662,00 & 5661,70 & 5661,70 & 0,00 \\
\hline
\end{tabular}

Źródło: Raport o stanie sektora małych i średnich przedsiębiorstw w Polsce w latach 2007-2008, Polska Agencja Rozwoju Przedsiębiorczości 2009, s. 27.

\section{Udzial MŚP w tworzeniu miejsc pracy}

Sektor MŚP w Polsce odgrywa ważną rolę w tworzeniu miejsc pracy, co potwierdzają dane dotyczące wielkości i struktury zatrudnienia w Polsce w tym sektorze. Według danych GUS na koniec 2007 roku liczba pracujących w przedsiębiorstwach ogółem wynosiła 8,9 mln osób, w tym w MŚP ponad 6,2 mln, natomiast w roku akcesji Polski do Unii Europejskiej liczba pracujących w MŚP była niższa i wynosiła 5,8 $\mathrm{mln}$, por. tab. 5 . 
Po akcesji Polski do Unii Europejskiej przeciętna liczba zatrudnionych w MŚP, po niewielkim spadku w 2004 roku, wzrosła rok później do poziomu 5,8 mln osób, a następnie w roku 2006 do ponad 5,9 mln osób. Dynamika wzrostu zatrudnienia w MŚP była niższa niż dynamika zatrudnienia w przedsiębiorstwach ogółem, bowiem ogólne zatrudnienie wzrosło o 830 tys., a w MŚP o 391 tys.

Tab. 5. Liczba pracujących w przedsiębiorstwach ogółem i w przedsiębiorstwach MŚP w latach 2003-2009 w mln osób

\begin{tabular}{|c|c|c|c|c|c|}
\hline Przedsiębiorstwa & $\mathbf{2 0 0 3}$ & $\mathbf{2 0 0 4}$ & $\mathbf{2 0 0 5}$ & $\mathbf{2 0 0 6}$ & $\mathbf{2 0 0 7}$ \\
\hline $\begin{array}{c}\text { Przedsiębiorstwa } \\
\text { ogółem }\end{array}$ & 8,139 & 8,161 & 8,288 & 8,556 & 8,969 \\
\hline MŚP ogółem & 5,829 & 5,812 & 5,869 & 5,993 & 6,220 \\
\hline Mikro & 3,397 & 3,384 & 3,403 & 3,475 & 3,593 \\
\hline Małe (bez mikro) & 0,954 & 0,967 & 0,972 & 0,977 & 1,008 \\
\hline Średnie & 1,479 & 1,462 & 1,494 & 1,542 & 1,619 \\
\hline
\end{tabular}

Źródło: dane Ministerstwa Gospodarki.

Analizując znaczenie MŚP w gospodarce, należy stwierdzić, iż byłoby ono znacznie większe, gdyby:

- liczba nowo powstałych firm szybciej wzrastała i wyprzedzałaby przedsiębiorstwa likwidowane w poszczególnych latach,

- dynamika wzrostu zatrudnienia w MŚP była wyższa,

- aktywność zarejestrowanych przedsiębiorstw w REGON była większa,

- okres przeżywalności przedsiębiorstw był dłuższy.

Sytuację w sektorze MŚP obrazuje liczba przedsiębiorstw nowo powstałych i likwidowanych, wzajemne relacje. W 2007 roku w stosunku do roku 2006 liczba nowo powstałych spadła o $0,8 \%$ przy równoczesnym spadku o $10,6 \%$ przedsiębiorstw zlikwidowanych, co wskazuje na poprawę sytuacji w sektorze MŚP. Problem przedsiębiorstw nowo powstałych i likwidowanych na przestrzeni 2003-2007 przedstawia ryc. 1 .

Ryc. 1. Liczba przedsiębiorstw nowo powstałych i zlikwidowanych w sektorze przedsiębiorstw w latach 2003-2007

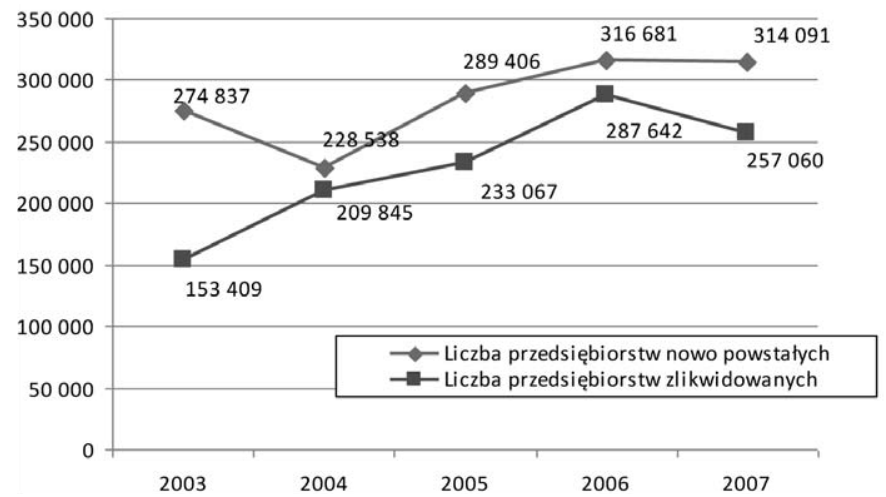

Źródło: Raport o stanie sektora małych i średnich przedsiębiorstw w Polsce w latach 2007-2008, Polska Agencja Rozwoju Przedsiębiorczości 2009, s. 30. 
Sytuacja przedsiębiorstw nowo powstałych i zlikwidowanych była zróżnicowana w poszczególnych klasach przedsiębiorstw. Według danych GUS jedynie w przypadku mikroi małych przedsiębiorstw liczba przedsiębiorstw nowo powstałych była wyższa niż liczba przedsiębiorstw zlikwidowanych w całym badanym okresie. Natomiast w grupie przedsiębiorstw średnich zanotowano największy rozdźwięk pomiędzy liczbą przedsiębiorstw nowych i zlikwidowanych.

Kolejnym kryterium oceny sytuacji w sektorze MŚP jest przeżywalność nowo powstałych przedsiębiorstw. Jest ona mierzona wskaźnikiem przeżycia pierwszego roku działalności firmy. Dla okresu 2003-2007 wskaźnik ten wahał się w granicach od 61,5\% do 67,6\%. Oznacza to, że ponad 1/3 przedsiębiorstw rok wcześniej powstałych upadła. W dłuższym okresie należy stwierdzić, że przeżywalność dramatycznie zmniejszała się w miarę upływu kolejnych lat. Przykładowo oznacza to, iż do roku 2007 przeżyło 66,5\% firm powstałych w 2006 roku i zaledwie 24,6\% powstałych w 2002 roku$^{8}$. Ponadto przedstawione w Raporcie dane $\mathrm{z}$ lat 2002-2006 pokazują, że poziom przeżywalności przedsiębiorstw utworzonych w 2002 roku spada średnio o $24,4 \%$ rocznie, co oznacza, że co roku ubywa $24,4 \%$ przedsiębiorstw powstałych w 2002 roku.

Podsumowując powyższe rozważania na temat znaczenia sektora MŚP w gospodarce i w jej wzroście, należy stwierdzić, iż mogłoby ono być większe, gdyby dynamika powstawania przedsiębiorstw była wyższa, aktywność większa a okres przeżywalności - dłuższy. Wymaga to usunięcia wielu barier ograniczających rozwój MŚP, do których zaliczyć należy:

- uciążliwe i skomplikowane procedury związane z podejmowaniem działalności gospodarczej, bariery prawne i instytucjonalne,

- wysokie koszty funkcjonowania przedsiębiorstw ograniczające poziom ich własnych zdolności akumulacyjnych,

- wysokie koszty pozyskiwania kredytów bankowych na rozwój i innowacyjność,

- niską zdolność kredytową przedsiębiorstw mikro i małych, powodującą, iż głównym narzędziem ich finansowania są środki własne,

- wciąż małe umiejętności przedsiębiorców w zakresie pozyskiwania i wykorzystania środków unijnych,

- niestabilność i skomplikowanie przepisów prawnych, wysokość podatków i składek na ubezpieczenia społeczne,

- niską krajową i międzynarodową konkurencyjność przedsiębiorstw sektora MŚP,

W usunięciu wymienionych barier oraz zwiększeniu konkurencyjności krajowej i międzynarodowej ważną rolę odgrywa pomoc publiczna. Co to jest pomoc publiczna, jaka jest dopuszczalna jej skala i formy?

\section{Pomoc publiczna dla małych i średnich przedsiębiorstw}

Pomoc publiczna dla małych i średnich przedsiębiorstw należy w teorii ekonomii do problemów bardzo kontrowersyjnych i złożonych. Podkreśla się, że ingerencja państwa ogranicza mechanizm rynkowy, odbywa się kosztem innych podmiotów oraz narusza reguły konkurencji będącej kołem zamachowym w gospodarce rynkowej. Głównymi kontrargumentami dla takiego podejścia do pomocy publicznej jest podkreślanie znaczenia sektora MŚP w gospodarce, w tworzeniu PKB, w kreacji nowych miejsc pracy, ich elastyczności w zakresie dostosowania się do zmieniającego się popytu oraz wpływu na przedsiębiorczość lokalną. Podkreśla się ponadto, że sektor ten charakteryzuje się gorszymi warunkami działania w porównaniu z dużymi

${ }^{8}$ Raport o stanie sektora..., op. cit. s. 32. 
przedsiębiorstwami, a co za tym idzie, brakiem szans na sprostanie konkurencji ze strony dużych przedsiębiorstw.

Złożoność pomocy publicznej wynika z wielu względów, w tym:

- trudności w zdefiniowaniu pomocy publicznej dostarczającej odpowiedzi na pytanie, co jest taką pomocą, a co nią nie jest,

- charakteru i formy pomocy publicznej dla małych i średnich przedsiębiorstw,

- identyfikacji mechanizmu jej oddziaływania na sytuację beneficjentów,

- metod jej finansowania, warunków przyznawania pomocy konkretnym podmiotom i szeregu innych spraw z nią związanych.

W związku z tym istnieje wiele definicji pomocy publicznej. Jedna z nich pomoc publiczną określa jako przysporzenie bezpośrednie lub pośrednie przez organy udzielające pomocy korzyści finansowych określonemu przedsiębiorcy w zakresie prowadzonej przez niego działalności gospodarczej. Cechą pomocy publicznej jest jej selektywność (podmiotowa i przedmiotowa) oraz doraźność.

Przysporzenie takie stanowi pomoc, jeżeli':

- jest realizowane bezpośrednio z krajowych środków publicznych lub z takich środków przekazywanych innym podmiotom albo pomniejsza lub może pomniejszyć te środki oraz

- narusza lub grozi naruszeniem konkurencji przez uprzywilejowanie niektórych przedsiębiorców lub produkcji niektórych towarów.

Przekazywane przez Unię Europejską środki na cele publiczne nie stanowią w pełni tego znaczenia pomocy publicznej, lecz są traktowane jako uzupełnienie ograniczonych krajowych środków publicznych ${ }^{10}$. Jest to podstawą wyróżnienia pomocy publicznej krajowej i pomocy z Unii Europejskiej udzielanej w ramach funduszy. Jednakże zgodnie z orzecznictwem Trybunału Sprawiedliwości, który pod pojęciem ,,pomocy państwa” rozumie się każdy środek, który poprawia sytuację przedsiębiorstwa z niej korzystającej. Stawia to w mniej korzystnej sytuacji przedsiębiorstwa nieotrzymujące takiej pomocy.

Natomiast w rozumieniu ustawy o swobodzie działalności gospodarczej (DzU 2004 r. nr 173, poz. 1807 z późn. zmianami) podmiotem pomocy publicznej jest przedsiębiorca. Jest to osoba fizyczna, osoba prawna oraz niemająca osobowości prawnej spółka prawa handlowego, która zawodowo, we własnym imieniu, podejmuje i wykonuje działalność gospodarczą. Działalnością gospodarczą w rozumieniu ww. ustawy jest zarobkowa działalność wytwórcza, handlowa, budowlana, usługowa oraz poszukiwanie, rozpoznawanie i eksploatacja zasobów naturalnych - wykonywana w sposób zorganizowany i ciagły.

Pomoc publiczna dla przedsiębiorców może przyjać różne formy, w tym ${ }^{11}$ :

- dokapitalizowanie przedsiębiorcy, także drogą nabycia przez państwo akcji lub udziałów tego przedsiębiorstwa,

- umorzenie zaległości wobec sektora publicznego,

- udzielenie gwarancji lub poręczenia, udzielenie kredytu lub pożyczki (celem tej pomocy jest wspieranie realizacji przedsięwzięć poprzez ułatwienie dokredytowania bankowego),

- udzielenie dotacji państwowych bez świadczeń ze strony przedsiębiorstwa ${ }^{12}$,

\footnotetext{
${ }^{9}$ E. Niemyska, Pomoc publiczna dla małych $i$ średnich przedsiębiorstw $w$ okresie dekoniunktury gospodarczej, Polska Agencja Informacji i Inwestycji.

${ }^{10}$ Pomoc publiczna dla małych $i$ średnich przedsiębiorstw. Mity i rzeczywistość, praca zbiorowa pod red.

F. Misiaga, PWE, Warszawa 2005, s. 8-14.

${ }^{11}$ Tamże, s. 81.

${ }^{12}$ Komentarz do Uktadu Europejskiego z 16 grudnia 1991, Urząd Rady Ministrów, Biuro ds. Integracji

Europejskiej oraz Pomocy Zagranicznej, Warszawa 1994, s. 169.
} 
- opłacenie części kosztów produkcji przez kogoś innego niż nabywca,

- uzyskanie przez producenta przywilejów obciążających finanse publiczne,

- przyznanie państwowych rekompensat na rzecz przedsiębiorstw.

W myśl przepisów obowiązujących w Unii Europejskiej wszelka pomoc przyznawana przez państwo członkowskie lub przy użyciu zasobów państwowych w jakiejkolwiek formie, która zakłóca lub grozi zakłóceniem konkurencji poprzez sprzyjanie niektórym przedsiębiorstwom lub produkcji niektórych towarów, jest niezgodna ze wspólnym rynkiem w zakresie, w jakim wpływa na wymianę handlową między państwami członkowskimi (art. 87 ust. 1 Traktatu o ustanowieniu Wspólnoty Europejskiej). Art. 87 Traktatu o ustanowieniu Wspólnoty Europejskiej generalnie zakazuje udzielania pomocy, uznając ją za niedopuszczalną, jeżeli:

- jest udzielana przez państwo lub ze środków publicznych,

- powoduje uprzywilejowanie niektórych przedsiębiorstw,

- zakłóca konkurencję lub grozi jej zakłóceniem,

- narusza wymianę handlową między państwami członkowskimi.

Jednakże dla wielu podmiotów pomoc publiczna jest niezbędna, oznacza być albo nie być na wspólnym rynku. Często ma ona miejsce, gdy zła sytuacja firmy powodowana jest czynnikami obiektywnymi. W związku z tym jest ona dozwolona warunkowo i tylko wtedy, jeżeli jej skutki ograniczają się jedynie do tego Państwa i gdy ${ }^{13}$ :

- pomoc została przyznana małym lub średnim przedsiębiorstwom (w każdym przypadku zakwalifikowanie do grupy mikro-, małych i średnich przedsiębiorstw zależy od: liczby zatrudnianych osób, wielkości obrotu i całkowitego bilansu rocznego ${ }^{14}$ ),

- pomoc nie przekracza określonego progu intensywności, rozumianego jako procentowy udział pomocy publicznej w danym działaniu,

- pomoc zawiera wyraźne nawiązanie do Rozporzqdzenia dotyczącego udzielenia pomocy MŚP, wskazującego między innymi to, na co przedsiębiorca może uzyskać pomoc. W Rozporzadzeniu wymienione zostały: inwestycje, doradztwo i udział w targach, badania i rozwój, prace badawczo-rozwojowe, pokrycie kosztów patentu, działania związane z ochroną środowiska naturalnego itp.

Pomoc państwa dla MŚP musi być również zgodna z wytycznymi Wspólnoty w sprawie pomocy państwa dla MŚP, aby nie dochodziło do zniekształcenia wymiany handlowej i konkurencji między krajami członkowskimi ${ }^{15}$. Szczególne znaczenie ma zgodność ze wspólnotową polityką konkurencji odnoszącą się do działania przedsiębiorstw i państw w obrębie Unii Europejskiej. W przypadku zachowań wypaczających konkurencję w obrębie wspólnego rynku Unia dysponuje odpowiednimi środkami prawnymi umożliwiającymi skuteczne zastosowanie sankcji.

Reasumując, zakaz pomocy publicznej dla przedsiębiorstw obowiązujący na terenie Unii Europejskiej nie ma charakteru bezwzględnego. Istnieje bowiem szereg wyłączeń regulowanych Rozporzadzeniem Komisji (WE) nr 70/2001 z dnia 12 stycznia 2001 roku w sprawie zastosowania art. 87 i 88 Traktatu WE w odniesieniu do pomocy dla małych i średnich przedsiębiorstw $^{16}$. Wynika z niego, iż pomoc udzielona MŚP spełniająca warunki Rozporzadzenia

\footnotetext{
${ }^{13}$ E. Niemyska, Pomoc publiczna dla matych i średnich przedsiębiorstw w okresie dekoniunktury gospodarczej, Polska Agencja Informacji i Inwestycji, s.12-13.

${ }^{14}$ Już w 1986 r. przyjęto na szczeblu Wspólnot program działania dla małych i średnich przedsiębiorstw, co uznaje się za początek wspólnej polityki wobec MŚP, Prawo konkurencji we Wspólnotach Europejskich, Warszawa 1998, s. 86-103.

${ }^{15}$ Artykuł 92 Traktatu Rzymskiego.

${ }^{16}$ Rozporządzenie, DzU WE L 10 z 13 stycznia 2001 roku, s. 33.
} 
jest zgodna ze wspólnym rynkiem w rozumieniu art. 87 ust. 3 Traktatu i jest wyłączona z obowiązku zgłoszenia Komisji Europejskiej określonego w art. 88 ust. 3 Traktatu.

Zgodnie z wytycznymi Komisji Europejskiej formy pomocy zostały podzielone na cztery grupy: A, B, C, D, por. tab. 4.

Tab. 6. Formy pomocy publicznej dla przedsiębiorstw sektora MŚP

\begin{tabular}{|c|c|c|c|}
\hline $\begin{array}{c}\text { GRUPA A } \\
\text { Dotacje i ulgi podatkowe }\end{array}$ & GRUPA B & $\begin{array}{c}\text { GRUPA C } \\
\text { Miękkie } \\
\text { kredytowanie }\end{array}$ & $\begin{array}{c}\text { GRUPA D } \\
\text { Poręczenia } \\
\text { i gwarancje } \\
\text { kredytowe }\end{array}$ \\
\hline $\begin{array}{l}\text { A1 - dopłaty do oprocentowa- } \\
\text { nia kredytów bankowych, inne } \\
\text { wydatki związane z funkcjo- } \\
\text { nowaniem jednostek budżeto- } \\
\text { wych lub realizację ich zadań } \\
\text { statutowych oraz refundacje } \\
\text { A2-zwolnienia z podatku, } \\
\text { odliczenia od podatku, obniżkę } \\
\text { lub zmniejszenie powodują- } \\
\text { ce obniżenie podstawy lub } \\
\text { wysokości podatku, zaniecha- } \\
\text { nie poboru opłaty, umorzenie } \\
\text { opłaty i odsetek z tytułu opłaty, } \\
\text { umorzenie kar, oddanie do } \\
\text { korzystania z mienia będącego } \\
\text { własnością Skarbu Państwa }\end{array}$ & $\begin{array}{l}\text { B1 - wniesienie } \\
\text { kapitału do spółki } \\
\text { B2- konwersja } \\
\text { wierzytelności na } \\
\text { akcje lub udziały }\end{array}$ & $\begin{array}{l}\text { C1 - pożyczki prefe- } \\
\text { rencyjne i warunkowo } \\
\text { umorzone, dopłaty } \\
\text { do oprocentowania } \\
\text { kredytów bankowych } \\
\text { (dla banków) } \\
\text { C2 - odroczenie lub } \\
\text { rozłożenie na raty } \\
\text { płatności: podatku lub } \\
\text { zaległości podatko- } \\
\text { wej, opłaty (czyli } \\
\text { składki), wpłaty, kary }\end{array}$ & $\begin{array}{l}\text { D1 - poręczenia } \\
\text { i gwarancje, gwa- } \\
\text { rancje bankowe }\end{array}$ \\
\hline
\end{tabular}

Źródło: opracowanie własne na podstawie Pomoc publiczna dla małych i średnich przedsiębiorstw. Mity i rzeczywistość, red. F. Misiąg, PWE, s. 82.

Ustanowienie warunków dopuszczalności pomocy publicznej przez państwo członkowskie jest gwarancją, że ingerencja państwa naruszająca konkurencję będzie stosowana dla uzyskania pozytywnych następstw, takich jak:

- restrukturyzacja gałęzi, branż i sektorów gospodarki,

- intensyfikacja inwestycji oddziaływujących na tworzenie miejsc pracy,

- zmniejszanie bezrobocia.

Pomoc publiczna dla małych i średnich przedsiębiorstw stała się przedmiotem licznych dyskusji prowadzonych w ramach forum lizbońskiego, sztokholmskiego czy barcelońskiego. Wspólną konkluzją tych dyskusji jest stwierdzenie, iż pomoc publiczna winna być pod kontrolą i że należy ją tam stosować, gdzie przynosi długookresowe pożądane efekty. Komisja Europejska wymusiła obniżenie pomocy publicznej w stosunku do PKB krajów członkowskich oraz zmianę jej przeznaczenia na cele horyzontalne ${ }^{17}$.

Od akcesji Polski do Unii Europejskiej pomoc publiczna udzielana przedsiębiorcom podlega ocenie pod względem zgodności z regułami wspólnego rynku i wymogami Komisji Europejskiej. Pomoc publiczna monitorowana jest również w innych krajach Unii Europejskiej.

${ }^{17}$ State Aid Policy in the Europan Community. A Guide for Practitioners, International Competition Law Series, 2005, Kluwer Law International, s. 6-9. 
W 2005 r. kraje UE-25 przeznaczyły na pomoc publiczną łącznie ok. 63,8 mld euro. Udział pomocy w PKB UE wyniósł 0,59\%. W Polsce ogólna wartość pomocy publicznej udzielonej przedsiębiorcom w tym okresie wyniosła 4795,1 mln zł (tj. 1191,2 mln euro, przyjmując średni kurs z 2004 roku: 1 euro = 4,0254 zł), a w relacji do PKB jej udział stanowił 0,5\%. Pomoc publiczna, bez pomocy w rolnictwie i transporcie, wyniosła w UE-25 - 45,1 mld euro, co stanowiło - 0,42\% PKB. W Polsce wartość pomocy, z wyłączeniem pomocy w transporcie i rolnictwie, wyniosła 3646,2 mln zł, tj. 0,4\% PKB.

W latach 1998-2006 na cele pomocy publicznej dla MŚP w UE przekazano ponad $744 \mathrm{mln}$ euro, z których skorzystało ponad 360000 MŚP. Wspomniana kwota została podwyższona do ponad 1 mld euro w Ramowym Programie na Rzecz Konkurencyjności i Innowacji (CIP) Komisji na lata 2007/2013. Wsparcie powinno umożliwić instytucjom finansowym przekazanie około 30 mld euro nowego finansowania dla około 475000 MŚP w Europie. Średnio każde euro wydane z budżetu UE powinno umożliwić prywatnym inwestorom przekazanie 6 euro kapitału podwyższonego ryzyka lub bankowi 50 euro kredytu.

Instrumenty finansowe obejmują różne potrzeby MŚP - zarówno nowo zakładanych, jak i działających firm. Przykładowo instrument na rzecz wysokiego wzrostu i innowacji w MŚP (GIF) udostępnia kapitał podwyższonego ryzyka innowacyjnym MŚP na początku działalności oraz na etapie rozwoju. Natomiast instrument gwarancyjny dla MŚP udostępnia gwarancje kredytowe, które zachęcają banki do pożyczania pieniędzy MŚP, zmniejszając tym samym ryzyko ponoszone przez banki. Podkreślić należy, iż grupa Europejskiego Banku Inwestycyjnego (EBI) rozszerza swoje działania wspierające MŚP, upraszczając mechanizmy finansowania, czyniąc je bardziej przejrzystymi i lepiej ukierunkowanymi na indywidualne potrzeby małych firm w Europie. MŚP zostaną udostępnione dodatkowe środki, a także inne rodzaje wsparcia finansowego - w tym finansowanie typu mezzanine, gwarancje i mikrokredyty. Instytucje finansowe dostosują je do uwarunkowań lokalnych i konkretnych potrzeb firm ${ }^{18}$.

\section{Podsumowanie}

Z przeprowadzonych rozważań wynika, iż małe i średnie przedsiębiorstwa w Polsce, podobnie jak w innych krajach Unii Europejskiej odgrywają ogromną rolę. Świadczy o tym między innymi to, iż stanowią one ponad 99,\% wszystkich przedsiębiorstw, a ich liczba wzrosła do ponad 3,79 mln. W 2007 roku sektor MŚP wytwarzał prawie 48\% PKB i zatrudniał 8,9 mln osób.

Rola małych i średnich przedsiębiorstw w Polsce mogłaby być znacznie większa, gdyby wskaźnik aktywności kształtujący się obecnie poniżej 50\% był wyższy, a okres przeżywalności. Ponadto ważnym warunkiem jest poprawa zdolności inwestycyjnej tych przedsiębiorstw i zwiększenie nakładów na badania. Wciąż około 50\% przedsiębiorców nie realizuje żadnych inwestycji ani badań.

Sektor małych i średnich przedsiębiorstw w Unii Europejskiej, w tym w Polsce może otrzymać pomoc publiczną warunkową. W szczególności dotyczy ona wydatków na badania lub rozwój, inwestycje, restrukturyzacje, likwidacje bezrobocia itp. Na pomoc taką nie mogą liczyć większe przedsiębiorstwa, tj. przedsiębiorstwa zatrudniające co najmniej 250 pracowników i których roczny obrót wynosi co najmniej $50 \mathrm{mln}$ euro, a całkowity bilans roczny wynosi co najmniej 43 mln euro.

Pomoc dla małych i średnich przedsiębiorstw nie może jednakże przekroczyć progu intensywności określonego jej udziałem w całkowitej realizacji projektu oraz nawiązywać do Rozporządzenia określającego zastosowanie Art. 86 oraz Art. 87 w sprawie pomocy publicznej.

${ }_{18}$ Stawiajac na mate firmy. Europa jest dobra dla MŚP, MŚP sq dobre dla Europy, wydanie 2008, s. $14-18$. 
Unia Europejska nadal pracuje nad poprawą sytuacji MŚP. Stworzyła politykę konkurencji chroniącą MŚP przed nieuczciwymi praktykami innych firm. Do głównych jej obszarów należy:

- ochrona przed nieuczciwymi praktykami dominujących firm,

- nie dla ,zmowy cenowej”.

Aktualizuje przepisy zachęcające rządy krajowe do dalszego ukierunkowania wsparcia ze środków publicznych, w myśl zasady „mniej pomocy a lepiej ukierunkowanej”. Chodzi o skierowanie pomocy na promowanie zatrudnienia, tworzenie nowych miejsc pracy oraz wsparcie publiczne nakierowane na usuwanie trudności napotykane przez MŚP.

Unia Europejska podejmuje działania na rzecz usunięcia barier w zakresie funkcjonowania MŚP, czego wyrazem jest Akt na rzecz drobnej przedsiębiorczości oraz szereg podejmowanych działań z zakresu wspólnej polityki konkurencji.

Polska jako kraj członkowski zobowiązana jest do przestrzegania unijnych regulacji prawnych w zakresie pomocy publicznej. Chodzi o to, aby pomoc publiczna w jak najmniejszym stopniu ograniczała konkurencję będącą głównym motorem rozwoju krajów Unii Europejskiej.

\section{Literatura}

1. Artykut 92 Traktatu Rzymskiego.

2. Eurostat, 2005, Kluczowe wskaźniki dla sektora niefinansowego, UE 27.

3. Komentarz do Układu Europejskiego z 16 grudnia 1991, Urząd Rady Ministrów, Kraków 2008.

4. Misiag F. (red.), 2005, Pomoc publiczna dla małych i średnich przedsiębiorstw. Mity i rzeczywistość, PWE, Warszawa.

5. Niemyska E., 2008, Pomoc publiczna dla małych i średnich przedsiębiorstw w okresie dekoniunktury gospodarczej, Polska Agencja Informacji i Inwestycji, Warszawa.

6. Pach J., 2008, Znaczenie matych i średnich przedsiębiorstw po 2000 roku [w:] Rola przedsiębiorczości w gospodarce opartej na wiedzy, red. Z. Zioło i T. Rachwał, Warszawa-Kraków.

7. Raport o stanie sektora matych i średnich przedsiębiorstw w Polsce $w$ latach 2007-2008, Polska Agencja Przedsiębiorczości 2009.

8. Raport o stanie sektora matych i średnich przedsiębiorstw w Polsce $w$ latach 2003-2008, Polska Agencja Przedsiębiorczości 2009.

9. State Aid Policy in the European Community. A Guide for Practitioners, International Competition Law Series, Kluwer Law International, 2005.

10. Stawiajac na mate firmy. Europa jest dobra dla MŚP, MŚP sq dobre dla Europy, Komisja Europejska, Przedsiębiorstwa i przemysł, Wydanie 2008.

11. Zoltan J. Acs, Young B., 1995, Small and Medium Sized Enterprises in the Global Economy, University of Maryland. 


\section{The problem of state aid for small and medium enterprises (SME) in Poland after its accession to the European Union}

Small and medium enterprises (SME) play an important role both in Poland and other countries of the European Union. Their contribution both as a percentage of the total number of enterprises, in general employment and in the production of particular products and gross domestic product confirms their importance for economy.

The role of SME in Poland would be greater if the indicator of their activity (which is now below 50\%) was higher, and the sustainability of SME's was improved. Moreover, the crucial condition for enlargement of SME's importance is the improvement of their investment capacity and increasing expenditure on research and development in this sector. About 50\% of entrepreneurs fail to make any investments and do not conduct any research that determine national and international competitiveness. There are many reason for this situation, especially financial limitations, which can be supplemented by state aid. However, there are some restrictions on supporting SME's by government as a result of the Common European Competition Policy. One of its basic rules is prohibition of state aid that deforms and limits competition, which is a base of economic development. In this situation state aid is allowed only on condition that its implementation does not restrict competition. The size and type, conditions and circumstances of state aid and its duration are precisely stipulated by the regulations. 